https://doi.org/10.22319/rmcp.v11i1.4829

Technical note

\title{
In vitro ruminal degradation of carbohydrate fractions in tropical grasses fertilized with nitrogen
}

Erika Andrea Hernández ${ }^{\mathrm{a}}$

Francisco Indalecio Juárez Lagunes ${ }^{a^{*}}$

Alice N. Pell ${ }^{\mathrm{b}}$

Maribel Montero Lagunes ${ }^{c}$

Juan Manuel Pinos Rodríguez ${ }^{\text {a }}$

Robert W. Blake ${ }^{b}$

${ }^{a}$ Universidad Veracruzana. Facultad de Medicina Veterinaria y Zootecnia. 91710 Veracruz, Ver. México.

${ }^{\mathrm{b}}$ Cornell University. Department of Animal Science. Ithaca, NY. USA.

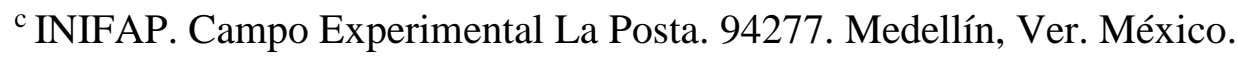

*Corresponding author: juarezf@hotmail.com

\begin{abstract}
:
The goal was to determine the digestion rates of carbohydrate fractions A (sugars, oligosaccharides and organic acids), $\mathrm{B}_{1}$ (starch and soluble fiber), NSC (non-structural carbohydrates) and $\mathrm{B}_{2}$ (available NDF) in four tropical grasses using the gas production technique. Samples of whole forage (WF), residue insoluble in 90\% ethanol (EIR) and isolated $\mathrm{NDF}$ (iNDF) were fermented in vitro and gas production measured. Gas volumes were determined from the following fractions, $\mathrm{A}=\mathrm{WF}$ minus EIR; $\mathrm{B}_{1}=\mathrm{EIR}-\mathrm{ND}$; NSC $=\mathrm{WF}$ iNDF; and $\mathrm{B}_{2}=\mathrm{iNDF}$. Grasses were Andropogon gayanus, Urochloa brizantha, Cynodon plectostachyus, and Megathyrsus maximus each grown in Veracruz, Mexico on four plots $(5 \times 5$ $\mathrm{m}$ ), fertilized (relationship equivalent to 0 and $100 \mathrm{~kg} \mathrm{~N} / \mathrm{ha}$ ) and clipped $35 \mathrm{~d}$ after the $\mathrm{N}$
\end{abstract}


fertilization. A complete randomized block design with factorial arrangement $4 \times 2$ and two replicates per treatment was used. Factors were grass species and $\mathrm{N}$ fertilization. Data were fit using a single-pool exponential model with lag. The volume ( $\mathrm{mL}$ gas $/ 100 \mathrm{mg} \mathrm{OM})$, rate $(\% / \mathrm{h})$ and lag (h) were: $\mathrm{WF}(22.8 ; 5.3 ; 2.1)$; A (3.2; 15.7; 0.5); $\mathrm{B}_{1}(1.5 ; 15.7 ; 0.2)$; and $\mathrm{B}_{2}(18.3 ; 6.6$; 5.2). Andropogon and Urochloa had higher NSC content compared to Megathyrsus and Cynodon but lower gas yield per unit of NSC. Rates of digestion for the $\mathrm{B}_{2}$ fraction ranged from 4 to $8 \% / \mathrm{h}$; and NSC digestion rate averaged $15.7 \% / \mathrm{h}$. Nitrogen fertilization reduced carbohydrate pool sizes but did not affect rates of digestion. It is concluded that the rates of digestion of the carbohydrate fractions differs by grass specie.

Key words: $\mathrm{C}_{4}$ grasses, Carbohydrate fractions, Digestion rates, Gas production, CNCPS model.

Received: 29/03/2018

Accepted: 13/11/2018

The energy content of forages that is available to the animal cannot be determined using standard analytical techniques. Therefore, other means are needed to estimate it. Past use of empirical prediction equations based on chemical composition, aided by detergent system analysis of fiber ${ }^{(1)}$ has been in the foundation for a comprehensive system of forage evaluation ${ }^{(2)}$. However, the underlying relationship between energy content and chemical composition is inconsistent in tropical forages with high contents of lignin, silica, tannins and other secondary compounds, which may interfere with digestion.

An alternative approach uses the In vitro ruminal digestion method ${ }^{(3)}$. This technique is commonly used to predict the digestibility of a feedstuff. However, measuring the extent of digestion by substrate disappearance has limitations: The soluble components are assumed to be completely digested and with similar energy values regardless of their carbohydrate or organic acid profiles ${ }^{(1)}$. The Cornell Net Carbohydrate and Protein System model (CNCPS) v.5 http://blogs.cornell.edu/cncps/ fractionates carbohydrates into three major fractions: fraction $\mathrm{A}$ (sugars, oligosaccharides and organic acids), fraction $\mathrm{B}_{1}$ (starch and soluble fiber), and fraction $\mathrm{B}_{2}$ (digestible structural carbohydrates) ${ }^{(4,5)}$. The CNCPS further partitions carbohydrates into eight digestible fractions ${ }^{(6)}: A_{1}$ (volatile fatty acids); $A_{2}$ (lactic acid); $A_{3}$ (other organic acids); $\mathrm{A}_{4}$ (sugars); $\mathrm{B}_{1}$ (starch); $\mathrm{B}_{2}$ (soluble fiber); $\mathrm{B}_{3}$ (available NDF); $\mathrm{C}$ (unavailable NDF). However, the CNCPS v6.5.5 ${ }^{(7)} \mathrm{http} / / / \mathrm{blogs} . c 0 r n e l l . e d u / c n c p s /$ model considers information only about the digestion rates of four fractions, $\mathrm{A}_{4}, \mathrm{~B}_{1}, \mathrm{~B}_{2}$ and $\mathrm{B}_{3}$. In this model (version 6.5.5), the rate of digestion assigned to the $A_{4}$ fraction $(40$ to $60 \% / h$ ) was 
obtained from data based on mixed ruminal microbes ${ }^{(8,9)}$ using the gas production technique ${ }^{(10)}$. This technique has been automated and used to estimate the digestion of the $\mathrm{NDF}^{(11)}$ and non-structural carbohydrates (NSC) ${ }^{(12)}$. Accordingly, fractions $\mathrm{B}_{1}$ and $\mathrm{B}_{2}$ have rates of 20 to $40 \% / \mathrm{h}$ and the $\mathrm{B}_{3}$ fraction rate varies between 1 and $18 \% / \mathrm{h}$.

The feed library of the Nutrient Requirements of Beef Cattle ${ }^{(13)}$ (https://www.nap.edu/download/19014) does not include tropical grasses. However, the Large Ruminant Nutrition System (LRNS) v1.033 ${ }^{(14)}$ (http://nutritionmodels.com/lrns.html) includes rates of digestion of carbohydrate fractions $\mathrm{A}, \mathrm{B}_{1}$ and $\mathrm{B}_{2}$ for tropical grasses. In this library grasses from Mexico ${ }^{(15)}$ are differentiated from Brazil, Honduras and Florida. The updated tropical library of the CNCPS v.6.5.5 ${ }^{(7)}$ validates the database from Mexico and correct the rates from Brazil, Honduras and Florida by assigning fixed values $(\% / \mathrm{h})$ of 40 for the $\mathrm{A}_{4} ; 30$ for $\mathrm{B}_{1} ; 30$ for $\mathrm{B}_{2}$; and 3.0 for $\mathrm{B}_{3}$ carbohydrate fractions. These last values are in agreement with previous reports ${ }^{(16-19)}$. However, more research is needed to update these rates.

Therefore, the objective of the present study was to chemically quantifying the carbohydrate fractions, $\mathrm{A}, \mathrm{B}_{1}, \mathrm{~B}_{2}$ and $\mathrm{C}$, and to measure the digestion kinetics of each of these fractions by measuring gas production in four tropical grasses fertilized with nitrogen.

The study was conducted at La Posta Experimental Station of Mexico's Instituto Nacional de Investigaciones Forestales Agrícolas y Pecuarias (INIFAP). This research station is located on the southeastern coast of Mexico in the State of Veracruz at $19^{\circ} 02^{\prime} \mathrm{N}$ and $96^{\circ} 08^{\prime} \mathrm{W}$, with an altitude of $12 \mathrm{~m}$ asl, a tropical subhumid Aw climate, with average annual rainfall of 1,728 $\mathrm{mm}, 25^{\circ} \mathrm{C}$ of average temperature and $81 \%$ relative humidity. The soil is classified as Oxisol, a predominantly sandy loam with $>15 \%$ clay and $1.7 \%$ organic matter, the $\mathrm{pH}$ was 5.35 . The soil chemical analysis report showed the follow mineral content (ppm): $\mathrm{P}_{2} \mathrm{O}_{5}, 12 ; \mathrm{K}, 108 ; \mathrm{Mg}$, $115 ; \mathrm{Ca}, 545 ; \mathrm{NO}_{3}, 9.5 ; \mathrm{S}, 16 ; \mathrm{Mn}, 13 ; \mathrm{Fe}, 53 ; \mathrm{Cu}, 0.45$; and $\mathrm{B}, 0.6$.

The selected grasses Andropogon gayanus, Urochloa brizantha, Cynodon plectostachyus, and Megathyrsus maximum Var. Guinea, are commonly used species. At the onset of the rainy season, each grass was grown in four plots $(5 \times 5 \mathrm{~m})$. Two plots were none fertilized, and the others were fertilized with $\mathrm{N}$ from urea (relationship equivalent to $100 \mathrm{~kg} \mathrm{~N} / \mathrm{ha}$ ). This dose is representative of that local livestock producers use. All plots were previously cut to a height of $5 \mathrm{~cm}$. There were two sampling periods (June 20 and July 25). After $35 \mathrm{~d}$ of regrowth, one sample of $2 \mathrm{~m}^{2}$ from the center of each plot was clipped at a height of $10 \mathrm{~cm}$. Samples were taken between 0700 to $0900 \mathrm{~h}$. A sub-sample of $500 \mathrm{~g}$ of green material was immediately frozen at $-15^{\circ} \mathrm{C}$, and another was placed in a forced air oven at $100{ }^{\circ} \mathrm{C}$ for $24 \mathrm{~h}$ to determine DM content and discarded. At the end of the sampling period (July 25), four frozen samples 
from each grass were lyophilized, placed in $30 \times 25 \mathrm{~cm}$ heavy-duty freezer bags, and sent to Cornell University (USA) for chemical analysis.

All samples were ground through a 1-mm screen in a Wiley mill (Model 4, Arthur H. Thomas Co. Philadelphia, PA). Dry matter for correction was determined by direct oven-drying of samples at $100^{\circ} \mathrm{C}$ overnight. Crude protein $(\mathrm{N} \times 6.25)$ was determined by a Macrokjeldahl procedure $^{(20)}$, modified using Boric acid at $4 \%$ concentration during distillation. Neutral detergent fiber (NDF) (without sodium sulfite), acid detergent fiber (ADF), nonstructural carbohydrates (NSC), neutral detergent insoluble protein (NDIP), and acid detergent insoluble protein (ADIP) were determined ${ }^{(21)}$. Permanganate lignin, cellulose and acid insoluble ash were also determined ${ }^{(22)}$. Hemicellulose was calculated as the difference of NDF minus ADF with appropriate correction for contents of ash and crude protein. Sugar content was determined by ethanol extraction (EIR) ${ }^{(23)}$.

Total carbohydrates and its fractions (NSC, A, $\mathrm{B}_{1}, \mathrm{~B}_{2}$, and $\mathrm{C}$ ) were estimated as follows:

Total carbohydrates $=100-\mathrm{CP}$ - ash - fat.

$\mathrm{C}$ fraction $=$ lignin $/ \mathrm{NDF} * 2.4$.

$\mathrm{B}_{2}$ fraction $=(\mathrm{NDF} / \mathrm{OM})-\mathrm{NDIP}-\mathrm{C}$ fraction.

A fraction $=(\mathrm{DM}-\mathrm{CP}-$ ash $)-($ ethanol insoluble residue $-\mathrm{CP}$ in ethanol insoluble residue ash in ethanol insoluble residue).

$\mathrm{NSC}=100-\mathrm{CP}-(\mathrm{NDF}-\mathrm{NDIP})-$ ash - fat.

$\mathrm{B}_{1}$ fraction $=$ NDS $-\mathrm{A}$.

The digestion kinetics of carbohydrate fractions were estimated from gas production measurements ${ }^{(11)}$ using the curve subtraction procedure ${ }^{(12)}$. To achieve this, the whole forage, ethanol insoluble residue (EIR) and the isolated NDF were fermented separately. For EIR ${ }^{(23)}$ five hundred milligrams of sample in $100 \mathrm{~mL}$ of $90 \% \mathrm{vol} / \mathrm{vol}$ ethanol were stirred for $4 \mathrm{~h}$. The sample was filtered through a 37- $\mu$ nylon mesh (Tetko ${ }^{\circledR}$, Briarcliff Manor, NY) and thrice rinsed with $90 \%$ ethanol without vacuum and once with acetone under vacuum. The sample then was dried at $50{ }^{\circ} \mathrm{C}$ overnight to remove residual acetone.

For the isolated $\mathrm{NDF}^{(11)}$ five hundred milligrams of sample and $100 \mathrm{~mL}$ of ND solution in $150-\mathrm{mL}$ serum bottles were autoclaved for $1 \mathrm{~h}$ at $105^{\circ} \mathrm{C}$. This NDF isolate was rinsed with hot water and $100 \mathrm{~mL}$ of ethanol, and filtered through a $37-\mu$ nylon mesh. Residual detergent was removed by soaking the isolate overnight at $39{ }^{\circ} \mathrm{C}$ in a solution of $1 \mathrm{M}\left(\mathrm{NH}_{4}\right)_{2} \mathrm{SO}_{4}(1 \mathrm{~g} \mathrm{NDF}$ to 
$\left.100 \mathrm{~mL} 1 \mathrm{M}\left(\mathrm{NH}_{4}\right)_{2} \mathrm{SO}_{4}\right)$. The isolate was again rinsed with hot water followed by $100 \mathrm{~mL}$ each of ethanol and acetone and air dried.

For the in vitro digestion ${ }^{(22)}$ the medium was boiled to remove dissolved gases and cooled, cysteine added, and $\mathrm{pH}$ adjusted to 6.8 as necessary. Sodium sulfide was replaced by an equal weight of cysteine hydrochloride to protect the pressure sensors used to monitor gas volume from traces of hydrogen sulfide. Ruminal fluid was collected approximately $4 \mathrm{~h}$ after feeding from two out of four mature, non-lactating, Holstein cows housed in the LARTU (Large Animal Research and Teaching Unit at Cornell University) and maintained on Timothy (Phleum pratense) hay Full Bloom (CP, 8\%; FDN, 65\%) similar quality than grasses of this study, in accordance with the Institutional Animal Care and Use Committee (IACUC) protocol.

At the outset of a fermentation, each $120 \mathrm{~mL}$ serum bottle contained $8 \mathrm{~mL}$ medium, $2 \mathrm{~mL}$ ruminal fluid, and $100 \mathrm{mg}$ of either whole forage, EIR, or isolated NDF. Gas production was measured every 20 min during a $48 \mathrm{~h}$ fermentation using a computerized monitoring system $^{(11,12)}$. The disappearance of NDF was determined at the end of each fermentation ${ }^{(11)}$. All gas volumes were corrected to standard atmospheric pressure $(760 \mathrm{~mm} \mathrm{Hg})$.

The estimation of digestion rates for the $\mathrm{A}, \mathrm{B}_{1}, \mathrm{~B}_{2}$, and NSC fractions by curve subtraction requires that the gas volume produced by the separate preparations (EIR and NDF) be adjusted to a common basis proportional to the content of each fraction within the whole forage ${ }^{(8)}$. Therefore, the gas volume produced was adjusted proportionally to the OM content of the whole forage.

Gas production during fermentation was recorded every $20 \min$ for $48 \mathrm{~h}$. On a point by point basis, data from the curve were subtracted from the gas produced by the larger fraction ${ }^{(8,24)}$. The gas from the A fraction was estimated by the difference between the gas yields from the whole forage sample and its EIR preparation. The $\mathrm{B}_{1}$ fraction was estimated by the difference between the EIR preparation and the isolated NDF. The $\mathrm{B}_{2}$ fraction is the gas produced from the fermentation of isolated NDF, and the NSC is the difference between the whole forage and its isolated NDF.

Kinetic analyses of cumulative gas production were obtained using a single pool exponential model with $\operatorname{lag}^{(25)}, \mathrm{Y}=\mathrm{a}^{*}\left(1-\exp \left(-\mathrm{b}^{*}(\mathrm{x}-\mathrm{c})\right)\right)$, where $\mathrm{Y}=$ volume of gas $\mathrm{mL} / 100 \mathrm{mg} \mathrm{OM}$ at time $\mathrm{x}$; $\mathrm{a}=$ maximum volume of gas, $\mathrm{mL} ; \mathrm{b}=$ rate constant of gas production, \%/h; $\mathrm{c}=$ lag term, h. The gas curves obtained by subtraction for the A, $\mathrm{B}_{1}$, and NSC fractions reached their asymptotes 
between 12 and $24 \mathrm{~h}$, indicating that these fractions had been depleted ${ }^{(12)}$. Afterwards changes in gas volume are related to microbial turnover, and potential non-additivity of the curve subtraction approach $^{(26,27)}$. For this reason, the gas curves for the A, $\mathrm{B}_{1}$ and NDS fractions were truncated for curve fitting after they plateaued ${ }^{(8)}$. All curves were fitted using the Table Curve (version 4.0, Jandel Scientific, San Rafael, CA).

A complete randomized block design with factorial arrangement and two replicates per treatment was used, where the factors were grass species and $\mathrm{N}$ fertilization. A laboratory standard of Guinea grass (M. maximum) was used to control for ruminal fluid variation among in vitro analyses. A $4 \times 2$ factorial arrangement of forage species (A. gayanus, U. brizantha, $C$. plectostachyus, or M. maximum Var. guinea) and $\mathrm{N}$ fertilization (0 and $100 \mathrm{Kg} / \mathrm{ha})$ as factors was used. Planned comparisons among the forages were evaluated using Tukey's W procedure. Results were deemed significant at $P \leq 0.05$ for the effects of grass species and fertilization. The ANOVA analyses were performed using the MINITAB, Version 10 (Minitab Inc., State College, PA) ${ }^{(28)}$. Because there were no interactions (grass* $\mathrm{N}$ fertilization) of the $4 \times 2$ factorial arrangement of treatments, only means of mean factors (grass or $\mathrm{N}$ fertilization) are shown in Tables 2 and 3.

Chemical composition by grass species and amount of $\mathrm{N}$ fertilization are presented in Table 1 . Under the same conditions of management and environmental growing conditions, the chemical composition of the grasses differed by species. Urochloa contained less NDF, neutral detergent insoluble protein (NDIP) and lignin than the other grasses. Andropogon had high NDIP and NSC levels. Megathyrsus, however, was distinguished for its high content of ash and acid insoluble ashes (AIA), and its low content (7.2\%) of CP. These values mirrored those found in the same similar-age species with climate Awo in Guerrero, Mexico ${ }^{(29)}$. Cynodon had high NDF and low NSC contents. Grasses varied in their distributions of chemical constituents, which reflects differences in morphology and physiology. Previous reports have indicated variations in the chemical composition of tropical grasses due to species $^{(30)}$, season of year ${ }^{(31)}$ and plant age ${ }^{(32,33)}$. Across these studies high amounts of ash in Megathyrsus, low lignin in Urochloa and low amounts of crude protein in Cynodon were consistently observed. The chemical constituent findings are consistent with other reports for Cynodon $^{(34)}$ Megathyrsus $^{(35)}$, Urochloa ${ }^{(36)}$ and Andropogon ${ }^{(29)}$, suggesting potential inherent growth differences in their plant tissues ${ }^{(33)}$. 
Table 1: Chemical composition (g/100g DM) of four tropical grasses fertilized with Nitrogen

\begin{tabular}{lllllllll}
\hline & $\begin{array}{l}\text { A. } \\
\text { gayanus }\end{array}$ & $\begin{array}{l}\text { U. } \\
\text { brizantha }\end{array}$ & $\begin{array}{l}\text { C. } \\
\text { plectosta- } \\
\text { chyus }\end{array}$ & $\begin{array}{l}\text { M. } \\
\text { maximus }\end{array}$ & SEM & $\begin{array}{l}\text { Non } \\
\text { fertilized }\end{array}$ & Fertilized & SEM \\
\hline Ash & $8.2^{\mathrm{c}}$ & $9.6^{\mathrm{b}}$ & $9.5^{\mathrm{b}}$ & $11.3^{\mathrm{a}}$ & 0.12 & $8.3^{\mathrm{b}}$ & $10.9^{\mathrm{a}}$ & 0.06 \\
$\mathrm{EE}$ & $2.0^{\mathrm{b}}$ & $2.4^{\mathrm{a}}$ & $1.3^{\mathrm{c}}$ & $2.6^{\mathrm{a}}$ & 0.05 & $1.6^{\mathrm{b}}$ & $2.5^{\mathrm{a}}$ & 0.03 \\
$\mathrm{CP}$ & $9.1^{\mathrm{a}}$ & $9.0^{\mathrm{a}}$ & $8.3^{\mathrm{ab}}$ & $7.2^{\mathrm{b}}$ & 0.12 & $5.9^{\mathrm{b}}$ & $10.9^{\mathrm{a}}$ & 0.06 \\
$\mathrm{NDF}$ & $69.8^{\mathrm{b}}$ & $66.4^{\mathrm{c}}$ & $74.9^{\mathrm{a}}$ & $69.1^{\mathrm{bc}}$ & 0.36 & $72.6^{\mathrm{a}}$ & $67.5^{\mathrm{b}}$ & 0.18 \\
$\mathrm{NDIP}$ & $4.4^{\mathrm{a}}$ & $1.2^{\mathrm{c}}$ & $3.1^{\mathrm{ab}}$ & $2.9^{\mathrm{b}}$ & 0.14 & $2.2^{\mathrm{b}}$ & $3.6^{\mathrm{a}}$ & 0.07 \\
$\mathrm{ADF}$ & $41.0^{\mathrm{a}}$ & $36.5^{\mathrm{b}}$ & $41.2^{\mathrm{a}}$ & $42.3^{\mathrm{a}}$ & 0.18 & $40.3^{\mathrm{a}}$ & $40.2^{\mathrm{a}}$ & 0.09 \\
$\mathrm{ADIP}$ & $0.6^{\mathrm{b}}$ & $0.3^{\mathrm{c}}$ & $0.8^{\mathrm{a}}$ & $0.6^{\mathrm{b}}$ & 0.02 & $0.5^{\mathrm{b}}$ & $0.7^{\mathrm{a}}$ & 0.01 \\
$\mathrm{AIA}$ & $4.3^{\mathrm{ab}}$ & $3.1^{\mathrm{c}}$ & $3.3^{\mathrm{bc}}$ & $5.0^{\mathrm{a}}$ & 0.13 & $3.5^{\mathrm{a}}$ & $4.4^{\mathrm{a}}$ & 0.06 \\
$\mathrm{Cel}$ & $32.2^{\mathrm{a}}$ & $29.7^{\mathrm{b}}$ & $32.3^{\mathrm{a}}$ & $33.0^{\mathrm{a}}$ & 0.09 & $32.4^{\mathrm{a}}$ & $31.2^{\mathrm{b}}$ & 0.05 \\
$\mathrm{Hem}$ & $28.2^{\mathrm{b}}$ & $31.3^{\mathrm{a}}$ & $33.1^{\mathrm{a}}$ & $28.3^{\mathrm{b}}$ & 0.22 & $33.1^{\mathrm{a}}$ & $27.3^{\mathrm{b}}$ & 0.11 \\
$\mathrm{NSC}$ & $16.5^{\mathrm{a}}$ & $14.7^{\mathrm{ab}}$ & $10.7^{\mathrm{c}}$ & $14.0^{\mathrm{b}}$ & 0.22 & $14.6^{\mathrm{a}}$ & $13.3^{\mathrm{b}}$ & 0.11 \\
Lig & $4.4^{\mathrm{b}}$ & $3.7^{\mathrm{c}}$ & $5.6^{\mathrm{a}}$ & $4.3^{\mathrm{bc}}$ & 0.06 & $4.5^{\mathrm{a}}$ & $4.5^{\mathrm{a}}$ & 0.03 \\
ETOH & $87.2^{\mathrm{ab}}$ & $85.5^{\mathrm{b}}$ & $89.1^{\mathrm{a}}$ & $87.9^{\mathrm{a}}$ & 0.22 & $87.3^{\mathrm{a}}$ & $87.5^{\mathrm{a}}$ & 0.11 \\
\hline
\end{tabular}

$\mathrm{EE}=$ ether extract; $\mathrm{CP}=$ crude protein; $\mathrm{NDF}=$ neutral detergent fiber; $\mathrm{NDIP}=$ neutral detergent insoluble protein; $\mathrm{ADF}=$ acid detergent fiber; $\mathrm{ADIP}=$ acid detergent insoluble protein; $\mathrm{AIA}=$ ash insoluble in acid; $\mathrm{Cel}=$ cellulose; $\mathrm{Hem}=$ hemicellulose; $\mathrm{NSC}=$ nonstructural carbohydrates; $\mathrm{Lig}=$ lignin; $\mathrm{ETOH}=$ residue insoluble in ethanol $90 \%$. a,b,c Means with different superscript differ $(P \leq 0.05)$ for the grass effect or for the fertilization effect.

Fertilization with $\mathrm{N}$ modified the amount and distribution pattern of the nutrients in these plants (Table 1). Protein contents were increased in both the cell wall and cell soluble fractions. Because amino acids and proteins in plants are synthesized from sugars ${ }^{(37)}$, an increase in $\mathrm{N}$ supply depresses the sugar content (less NSC). Fertilization also reduces the NDF content with most of this decrease occurring in hemicellulose, most of which is deposited in the secondary wall as plants mature. An increase in CP and reduction of NDF has also been found in Urochloa ruziziensis fertilized with $120 \mathrm{~kg} / \mathrm{N} / \mathrm{ha}$ and harvested at $30 \mathrm{~d}$ of regrowth ${ }^{(36)}$.

Chemical constituents of the plant cell have been used to mathematically predict the feedstuff energy available to the animal ${ }^{(37,38)}$. An alternative approach is to integrate digestion and passage rates using the relationship among different energy pools, $k_{d}=k_{d} /\left(k_{d}+k_{p}\right)$, where $K d$ is rate of digestion and $\mathrm{Kp}$ is rate of passage. The estimated carbohydrate pools of the grasses in our study are in Table 2. The total carbohydrate content ranged from 77.8 to $80.4 \% \mathrm{OM}$. The digestible NDF content ( $\mathrm{B}_{2}$ fraction) ranged from 47.8 to $51.2 \%$ on an $\mathrm{OM}$ basis with Andropogon containing the least and Cynodon the most. Conversely, the NSC content was greatest in Andropogon (17.4\% OM) and least in Cynodon (10.7\% OM). The C fraction (Lignin/NDF*2.4), which is assumed indigestible, ranged from 13.5 to $18.0 \%$ with the largest 
amount found in Cynodon and the least in Urochloa. As a proportion of NSC, the A fraction (sugars, organic acids and short chain polysaccharides) constituted $68 \%$ of the total with the $\mathrm{B}_{1}$ fraction (starch and soluble fiber) made up the remainder. While the $\mathrm{B}_{1}$ fraction in tropical forages contains the smallest pool of carbohydrates (mostly as starch), it nonetheless represents about one-third (30\%) of NSC. The carbohydrate pools in this study are in agreement with the values shown in the LRNS and CNCPS feed libraries. Grasses elsewhere of the same species have been found that the $\mathrm{B}_{1}$ is the smallest $\mathrm{CHO}$ fraction and that is made of starch mainly ${ }^{(39)}$. The NSC is a complex fraction where the starch is part of the non-fiber carbohydrates (NFC) and the pectin substances are part of the structural carbohydrates unaccounted in the $\mathrm{B}_{2}$ fraction.

Table 2: Carbohydrate fractions $(\mathrm{g} / 100 \mathrm{~g} \mathrm{OM})$ of four tropical grasses fertilized with Nitrogen

\begin{tabular}{cllllllll}
\hline & $\begin{array}{l}\text { A. } \\
\text { gayanus }\end{array}$ & $\begin{array}{l}\text { U. } \\
\text { brizantha }\end{array}$ & $\begin{array}{l}\text { C. } \\
\text { Plectosta- } \\
\text { chyus }\end{array}$ & $\begin{array}{l}\text { M. } \\
\text { maximus }\end{array}$ & SEM & $\begin{array}{l}\text { Non } \\
\text { fertilized }\end{array}$ & Fertilized & SEM \\
\hline $\mathrm{CHO}$ & $80.4^{\mathrm{a}}$ & $79.7^{\mathrm{a}}$ & $79.9^{\mathrm{a}}$ & $77.8^{\mathrm{b}}$ & 0.12 & $83.7^{\mathrm{a}}$ & $75.2^{\mathrm{b}}$ & 0.06 \\
$\mathrm{~A}$ & $10.6^{\mathrm{a}}$ & $10.8^{\mathrm{a}}$ & $7.9^{\mathrm{b}}$ & $9.6^{\mathrm{ab}}$ & 0.19 & $10.5^{\mathrm{a}}$ & $9.0^{\mathrm{b}}$ & 0.10 \\
$\mathrm{~B}_{1}$ & $6.8^{\mathrm{a}}$ & $4.7^{\mathrm{ab}}$ & $2.7^{\mathrm{b}}$ & $4.0^{\mathrm{b}}$ & 0.26 & $4.5^{\mathrm{a}}$ & $4.6^{\mathrm{a}}$ & 0.13 \\
$\mathrm{NSC}$ & $17.4^{\mathrm{a}}$ & $15.5^{\mathrm{ab}}$ & $10.7^{\mathrm{c}}$ & $13.6^{\mathrm{b}}$ & 0.24 & $15.0^{\mathrm{a}}$ & $13.6^{\mathrm{b}}$ & 0.12 \\
$\mathrm{~B}_{2}$ & $47.8^{\mathrm{b}}$ & $50.6^{\mathrm{ab}}$ & $51.2^{\mathrm{a}}$ & $49.4^{\mathrm{ab}}$ & 0.32 & $53.9^{\mathrm{a}}$ & $45.6^{\mathrm{b}}$ & 0.16 \\
$\mathrm{C}$ & $15.2^{\mathrm{b}}$ & $13.5^{\mathrm{b}}$ & $18.0^{\mathrm{a}}$ & $14.8^{\mathrm{b}}$ & 0.20 & $14.8^{\mathrm{b}}$ & $16.0^{\mathrm{a}}$ & 0.10 \\
\hline
\end{tabular}

$\mathrm{CHO}=$ total carbohydrate content, $\% \mathrm{OM}=100-\mathrm{CP}$-ash-fat; $\mathrm{A}=$ (dry matter corrected for $\mathrm{CP}$ and Ash) - (residue remaining after extraction with $90 \%$ ethanol corrected for $\mathrm{CP}$ and ash); $\mathrm{B}_{1}=\mathrm{NSC}-\mathrm{A} ; \mathrm{NSC}=$ Non-structural carbohydrates $=100$-Crude protein-(NDF-NDIP)-fat-ash; $\mathrm{B}_{2}=\mathrm{NDF}$ on organic matter basis minus NDIP minus the $\mathrm{C}$ fraction; $\mathrm{C}=\mathrm{Lignin} / \mathrm{NDF} * 2.4$.

${ }^{a, b, c}$ Class means with different superscript differ $(P<0.05)$ for grass effect or for fertilizer effect.

Nitrogen fertilization had a dual negative impact on carbohydrate pools (Table 2). First, the total plant carbohydrate was reduced due to a smaller A pool. An increase in the $\mathrm{N}$ fractions requires a corresponding depression in non-nitrogen components, especially sugars ${ }^{(37)}$. Second, the $\mathrm{B}_{2}$ pool was reduced by $15.4 \%$. At different levels of $\mathrm{N}$ fertilization the same effect on NDF it has been demonstrated ${ }^{(36)}$. The positive effect of $\mathrm{N}$ fertilization in reducing the NDF content is offset by a negative effect in increasing lignification. The net result is a reduction in the availability of the $\mathrm{B}_{2}$ fraction and an increase in the indigestible (C) fraction. The overall effect on the plant is a reduction in the available total carbohydrates. This may be why there are no improvements in IVDMD with $\mathrm{N}$ fertilization ${ }^{(36)}$. CNCPS predictions ${ }^{(15)}$ found that the lower NDF in nitrogen fertilized tropical grasses was offset by higher $\mathrm{CP}$ and ash, which lowered the content of NSC. As a result, nitrogen fertilization did not significantly change the ME allowable milk. However, it improved the MP allowable milk dramatically. Because $\mathrm{N}$ fertilization increased both the $\mathrm{CP}$ and soluble protein content of the grasses, both 
the ruminal $\mathrm{N}$ balance and the peptide balance increased. Juarez-Lagunes et $a l^{(19)}$ concluded that $\mathrm{N}$ fertilization could be expected to improve MP allowable milk, primarily because of increased pool sizes of $\mathrm{CP}$ and soluble protein.

Another challenge is to establish a connection between carbohydrate pools, energy yield from rumen fermentation and gas production. Gas production is not only affected by the amount of carbohydrates in a given pool, but it is also by their availability. Ranges from 27 to $30 \mathrm{~mL}$ of gas per 100mg of OM where found in whole forages in this study. Similar gas production was observed in 24 tropical grass species in Ethiopia ${ }^{(40)}$. Cynodon produced less gas than Megathyrsus (Table 3) because Cynodon contains a larger C fraction than Megathyrsus (Table 2). A large $C$ fraction indicates low availability of the cell wall. However, the $C$ fraction does not explain the low availability of NSC. It is generally assumed that the NSC fraction is highly digestible ${ }^{(37)}$. Because Andropogon has more total carbohydrates with the same $\mathrm{C}$ fraction size as Megathyrsus (Table 2), Andropogon should be expected to yield more gas than Megathyrsus. However, gas yields were similar (Table 3). Something may interfere with gas production from Andropogon.

Volumes of gas produced by the NSC also are shown in Table 3. Andropogon and Urochloa contain more NSC than Cynodon and Megathyrsus (Table 2), but they produce the same volume of gas from the NSC fraction. Moreover, the amount of gas per $100 \mathrm{mg}$ of NSC is reduced suggesting that fermentations of the NSC of Andropogon and Urochloa were inhibited. Based on the subtraction technique, the fermentability of the A fraction of Urochloa and the $\mathrm{B}_{1}$ fraction of Andropogon seemingly were affected. We suspect that tannin-like substances (TLS) $)^{(41)}$ or other secondary compounds interfere in the fermentability of NSC. During the preparation of the isolated NDF; tannins, biogenic silica or other secondary compounds are washed out, so the fermentability of the isolated NDF would be affected only by lignin content. 
Rev Mex Cienc Pecu 2020;11(1):266-282

Table 3: Gas production and digestion rates of four tropical grasses fertilized with Nitrogen

\begin{tabular}{|c|c|c|c|c|c|c|c|c|}
\hline & $\begin{array}{l}\text { A. } \\
\text { Gaya- } \\
\text { nus }\end{array}$ & $\begin{array}{l}U . \\
\text { Brizan- } \\
\text { tha }\end{array}$ & $\begin{array}{l}\text { C. } \\
\text { Plectosta- } \\
\text { chyus }\end{array}$ & $\begin{array}{l}\text { M. } \\
\text { Maxi- } \\
\text { mus }\end{array}$ & SEM & $\begin{array}{l}\text { Non } \\
\text { fertilized }\end{array}$ & $\begin{array}{l}\text { Fertili- } \\
\text { zed }\end{array}$ & SEM \\
\hline \multicolumn{9}{|l|}{ Total carbohydrates } \\
\hline Total gas, mL & $23.7^{\mathrm{a}}$ & $23.0^{\mathrm{a}}$ & $21.6^{b}$ & $23.6^{\mathrm{a}}$ & 0.11 & $24.0^{\mathrm{a}}$ & $21.9^{b}$ & 0.05 \\
\hline $\begin{array}{l}\text { Gas, } \mathrm{mL} / 100 \mathrm{mg} \\
\text { OM }\end{array}$ & $29.5^{\mathrm{ab}}$ & $28.9^{\mathrm{b}}$ & $27.1^{\mathrm{c}}$ & $30.3^{\mathrm{a}}$ & 0.15 & $28.7^{\mathrm{a}}$ & $29.2^{\mathrm{a}}$ & 0.07 \\
\hline $\begin{array}{l}\text { Degradation rate, } \\
\% / \mathrm{h}\end{array}$ & $5.1^{\mathrm{ab}}$ & $5.2^{\mathrm{ab}}$ & $4.8^{\mathrm{b}}$ & $6.0^{\mathrm{a}}$ & 0.10 & $4.9^{\mathrm{b}}$ & $5.7^{\mathrm{a}}$ & 0.05 \\
\hline Lag phase, h & $2.2^{\mathrm{b}}$ & $2.4^{\mathrm{b}}$ & $1.0^{\mathrm{c}}$ & $3.0^{\mathrm{a}}$ & 0.06 & $2.1^{\mathrm{a}}$ & $2.2^{\mathrm{a}}$ & 0.03 \\
\hline \multicolumn{9}{|l|}{$\mathrm{B}_{2}$ fraction } \\
\hline Total gas, mL & $19.4^{\mathrm{a}}$ & $18.6^{\mathrm{ab}}$ & $17.5^{\mathrm{c}}$ & $18.4^{\mathrm{ab}}$ & 0.14 & $19.2^{\mathrm{a}}$ & $17.8^{b}$ & 0.07 \\
\hline $\begin{array}{l}\text { Gas, } \mathrm{mL} / 100 \mathrm{mg} \\
\text { OM }\end{array}$ & $40.9^{\mathrm{a}}$ & $36.9^{\mathrm{ab}}$ & $34.0^{\mathrm{b}}$ & $37.3^{\mathrm{ab}}$ & 0.43 & $35.3^{\mathrm{b}}$ & $39.2^{\mathrm{a}}$ & 0.21 \\
\hline $\begin{array}{l}\text { Degradation rate, } \\
\% / \mathrm{h}\end{array}$ & $7.3^{\mathrm{ab}}$ & $8.4^{\mathrm{a}}$ & $3.8^{\mathrm{c}}$ & $6.8^{\mathrm{b}}$ & 0.16 & $6.5^{\mathrm{a}}$ & $6.6^{\mathrm{a}}$ & 0.08 \\
\hline Lag phase, $\mathrm{h}$ & $4.5^{\mathrm{b}}$ & $5.2^{\mathrm{b}}$ & $4.6^{\mathrm{b}}$ & $6.7^{\mathrm{a}}$ & 0.14 & $5.2^{\mathrm{a}}$ & $5.3^{\mathrm{a}}$ & 0.07 \\
\hline \multicolumn{9}{|l|}{ NSC fraction } \\
\hline Total gas, mL & $4.3^{\mathrm{b}}$ & $4.4^{\mathrm{b}}$ & $4.1^{\mathrm{b}}$ & $5.2^{\mathrm{a}}$ & 0.08 & $4.8^{\mathrm{a}}$ & $4.1^{\mathrm{b}}$ & 0.04 \\
\hline $\begin{array}{ll}\text { Gas, } & \mathrm{mL} / 100 \quad \mathrm{mg} \\
\text { OM } & \end{array}$ & $24.5^{\mathrm{b}}$ & $28.1^{\mathrm{b}}$ & $38.6^{\mathrm{a}}$ & $38.6^{\mathrm{a}}$ & 0.90 & $34.1^{\mathrm{a}}$ & $30.8^{\mathrm{a}}$ & 0.45 \\
\hline $\begin{array}{l}\text { Degradation rate, } \\
\% / \mathrm{h}\end{array}$ & $13.8^{\mathrm{b}}$ & $27.4^{\mathrm{a}}$ & $13.2^{\mathrm{b}}$ & $8.6^{\mathrm{b}}$ & 0.77 & $17.5^{\mathrm{a}}$ & $14.0^{\mathrm{a}}$ & 0.38 \\
\hline Lag phase, h & $1.2^{\mathrm{a}}$ & $0.5^{\mathrm{a}}$ & $0.1^{\mathrm{b}}$ & $0.6^{\mathrm{a}}$ & 0.11 & $0.3^{\mathrm{a}}$ & $0.8^{\mathrm{a}}$ & 0.05 \\
\hline A fraction ${ }^{1}$ & & & & & & & & \\
\hline Total gas, mL & $3.3^{\mathrm{a}}$ & $2.0^{\mathrm{b}}$ & $3.4^{\mathrm{a}}$ & $3.2^{\mathrm{a}}$ & 0.08 & $3.2^{\mathrm{a}}$ & $2.7^{\mathrm{b}}$ & 0.04 \\
\hline $\begin{array}{l}\text { Gas, } \mathrm{mL} / 100 \mathrm{mg} \\
\mathrm{OM}\end{array}$ & $31.7^{\mathrm{b}}$ & $18.2^{\mathrm{c}}$ & $42.6^{\mathrm{a}}$ & $33.4^{\mathrm{b}}$ & 0.72 & $32.0^{\mathrm{a}}$ & $31.0^{\mathrm{a}}$ & 0.36 \\
\hline \multicolumn{9}{|l|}{$\mathrm{B}_{1}$ fraction $^{1}$} \\
\hline Total gas, mL & $0.9^{\mathrm{b}}$ & $2.4^{\mathrm{a}}$ & $0.7^{\mathrm{b}}$ & $2.0^{\mathrm{a}}$ & 0.09 & $1.6^{\mathrm{a}}$ & $1.4^{\mathrm{a}}$ & 0.05 \\
\hline $\begin{array}{l}\text { Gas, } \mathrm{mL} / 100 \mathrm{mg} \\
\text { OM }\end{array}$ & $13.8^{b}$ & $54.7^{\mathrm{a}}$ & $24.4^{\mathrm{ab}}$ & $51.4^{\mathrm{a}}$ & 3.44 & $39.8^{\mathrm{a}}$ & $32.3^{\mathrm{a}}$ & 1.72 \\
\hline
\end{tabular}

Total carbohydrates $=100-\mathrm{CP}-$ Ash - Fat.

$\mathrm{B}_{2}$ fraction= digestible structural carbohydrates= NDF/OM - NDIP $-\mathrm{C}$ fraction.

NSC fraction= non-structural carbohydrates= $100-$ CP $-($ NDF - NDIP $)-$ Ash - Fat.

A fraction $=$ sugars and short chain polysaccharides $=($ dry matter corrected for $\mathrm{CP}$ and Ash $)-($ residue remaining after extraction with $90 \%$ ethanol corrected for $\mathrm{CP}$ and Ash).

$\mathrm{B}_{1}$ fraction $=$ starch and soluble fiber $=$ NSC $-\mathrm{A}$.

${ }^{1}$ Degradation rates $(\% / \mathrm{h})$ and Lag phases $(\mathrm{h})$ for $\mathrm{A}$ fraction and $\mathrm{B}_{1}$ fraction were similar to NSC fraction.

a,b,c Means with different superscript differ $(P \leq 0.05)$ for the grass effect and for the fertilization effect. 
When it was applied curve subtraction to NSC (whole forage - isolated NDF) all potentially interfering substances (tannins, biogenic silica or secondary compounds) were accounted in the NSC fraction, thus reducing gas yield. In our case, digestibility of the isolated NDF was $6.6 \%$ greater than for whole forage NDF. These differences were $6.9 \%$ for Andropogon and Urochloa, and $6.2 \%$ for Cynodon and Megathyrsus. As a result, it may have experienced some under-prediction of NSC gas production. Because the amounts of soluble silica were similar in Cynodon and Megathyrsus compared to Andropogon and Urochloa (see AIA in Table 1), it was assumed that the major source of variation in gas produced by the NSC fraction likely resulted from secondary compounds. In a botanical survey Megathyrsus did not contain TLS, which obtains maximum expression in A. gayanus ${ }^{(41)}$. In the study Urochloa did not appear to contain condensed tannins, however it is suspect that there indeed may be other interfering substances. These findings support the suggestion that lignin content should be added to the equation to estimate total carbohydrates by the CNCPS model. Therefore, this modified CNCPS equation would become:

$\mathrm{CHO}(\mathrm{g} / \mathrm{kg} \mathrm{DM})=1000-[\mathrm{CP}(\mathrm{g} / \mathrm{kg} \mathrm{DM})+\mathrm{EE}(\mathrm{g} / \mathrm{kg} \mathrm{DM})+\mathrm{MM}(\mathrm{g} / \mathrm{kg} \mathrm{DM})+\mathrm{Lignin}(\mathrm{g} / \mathrm{kg}$ $\mathrm{DM})]$

The interference by phenols in the digestion of legumes and grasses merits more study for better management of ruminant nutrition in the tropics.

Nitrogen fertilization reduced the total amount of carbohydrates available for rumen fermentation (Table 2). The volume of gas produced was proportionally diminished with the amount of carbohydrate (Table 3). For instance, there was no difference in the amount of gas per $100 \mathrm{mg}$ of substrate from unfertilized and fertilized forages. In the $\mathrm{B}_{2}$ fraction, fertilized forage (FE) produced less gas than unfertilized forage (NF) because FE contained less fermentable structural carbohydrates (SC). In this study of same-age forages, fertilized grasses contained less NDF and the same amount of lignin as a percentage of dry matter as unfertilized grasses (Table 1), as has been found by others ${ }^{(42,43)}$. Therefore, there was more lignin as a percentage of the NDF. On the other hand, the difference in SC content between $\mathrm{NF}$ and FE was due primarily to hemicellulose. It is known that hemicellulose has more complex linkages with lignin than cellulose ${ }^{(37)}$. Therefore, hemicellulose should be less available, increasingly so as the plant cell wall matures from more linkages between hemicellulose and lignin ${ }^{(33)}$. NF grasses contained more hemicellulose and more mature cell walls than $\mathrm{FE}^{(44)}$. The linkages between lignin and hemicellulose was reflected by the reduction in the amount of gas per $100 \mathrm{mg}$ of SC from the NF grasses (Table 3). In summary, fertilized grasses produced $7.3 \%$ less total gas from a smaller SC pool. However, this was compensated by $10 \%$ more gas per unit of SC because they are less mature than NF grasses at 
the same age.

Rates of digestion are presented also in Table 3. The range of the digestion rates obtained by the exponential equation for the whole forage was from 4.8 to $6.0 \% / \mathrm{h}\left(\mathrm{r}^{2}=99.7 \pm 0.12\right.$; $\mathrm{t}$ value $=61.2 \pm 12.04)$, which agrees with other reports ${ }^{(45)}$. For isolated NDF, digestion rates ranged from 3.8 to $8.4 \% / \mathrm{h}\left(\mathrm{r}^{2}=99.8 \pm 0.11\right.$; $\mathrm{t}$-value $\left.=62.6 \pm 14.07\right)$, values that were higher than in other reports ${ }^{(4,18,19)}$ of 2 to $4 \% / \mathrm{h}$ for the $\mathrm{B}_{2}$ fraction, and aligned with NDF digestion rates between 5.16 and 9.34 for $\mathrm{C} 4$ grasses $^{(46)}$, and corn silages ${ }^{(47)}$. Updated versions of nutrition models (CNCPS; LRNS; NRC) should incorporate these rates to more accurately estimate ruminally available energy from the $\mathrm{SC}$ in $\mathrm{C} 4$ grasses. In tropical grasses, the $\mathrm{B}_{2}$ fraction is the largest pool of carbohydrates, so the impact on the ME available to the animal could be significant. The ME allowable milk predicted by the $\operatorname{CNCPS}^{(15)}$ was very sensitive to change in the rate of digestion of the $\mathrm{B}_{2}$ carbohydrate fraction. The ME allowable milk increased $88 \%$ when the rate increased from 3 to $6 \% / \mathrm{h}$, and it increased an additional $24 \%$ when the rate increased from 6 to $9 \% / \mathrm{h}$. The predicted MP allowable milk increased from a 0.8 to $5.7 \mathrm{~kg} / \mathrm{d}$ as the $\mathrm{B}_{2}$ rate increased from 3 to $6 \% / \mathrm{h}$ and increased to $9.9 \mathrm{~kg} / \mathrm{d}$ with a $\mathrm{B}_{2}$ rate of $9 \% / \mathrm{h}$. These increases are the result of greater rumen degradation of SC.

In this study, because the $\mathrm{B}_{1}$ was less than $10 \%$ of the total $\mathrm{DM}$, it was combined the $\mathrm{A}$ and $\mathrm{B}_{1}$ rates and used the combined NSC rate for both fractions (Table 3). The rates for the NSC were highly variable, ranging from $8.6 \% / \mathrm{h}$ in Megathyrsus to $27.4 \% / \mathrm{h}$ in Urochloa $\left(\mathrm{r}^{2}=99.2 \pm\right.$ 0.52 ; $\mathrm{t}$-values $=13.7 \pm 6.83$ ), with an overall mean of $15.7 \% / \mathrm{h}$. These values are near the average $(13.7 \% / \mathrm{h})$ for bromegrass, orchardgrass, and alfalfa, where rates of digestion were $13.9 \% / \mathrm{h}$ for the $\mathrm{A}$ fraction and $11.8 \% / \mathrm{h}$ for the $\mathrm{B}_{1}$ fraction $^{(8)}$, also from Brazilian tropical grasses with rates of digestion for the NSC fraction between 6 and $12 \% / \mathrm{h}^{(48)}$. The CNCPS tabular values of digestion rates for the A fraction are fixed $40 \% / \mathrm{h}$ and for the $\mathrm{B}_{1}$ fraction are $30 \% / \mathrm{h}$ in most tropical grasses. There is need for more research on the rates of digestion of carbohydrate pools in tropical grasses, and more frequent revision of tabular values for field use. Nitrogen fertilization did not have much apparent influence on rates of digestion (Table 3 ). These were apparently more affected by inherent plant physical structure. Chemical differentiation was more related to the extent of digestion and volume of gas produced ${ }^{(48)}$. Tissue anatomy strongly affects degradation rates. Cell types with thickened secondary wall, such as vascular bundles, sclerenchyma strands, epidermis and parenchyma bundle sheath of $\mathrm{C}_{4}$ grass leaves form solid, multicellular blocks of cells that constitute a barrier to microbial access to wall surfaces ${ }^{(49)}$. If all cells had only thin primary walls, (e.g., mesophyll, phloem and undifferentiated parenchyma tissues of leaves and young stems) then the cell wall would degrade rapidly. 
In summary, chemically Andropogon and Urochloa had more NSC compared with Megathyrsus and Cynodon but they produced less gas per unit of NSC. It is suspected interference from secondary compounds. The rates of digestion for the $\mathrm{B}_{2}$ fraction ranged from 4 to $8 \% / \mathrm{h}$ and the rate of digestion for the NSC averaged $15.7 \% / \mathrm{h}$. Nitrogen fertilization had a negative impact on carbohydrate pool sizes but did not affect rates of digestion.

Digestion rates found in this study suggest that the CNCPS, LRNS and NRC should update more frequently the ruminally available energy from SC and NSC in tropical forages. The impact on the prediction of the ME available to the animal could be significantly improved.

\section{Acknowledgements}

This work was funded by Cornell University Animal Science Department, USA.

\section{Literature cited:}

1. Van Soest PJ. Use of detergents in the analysis of fibrous feeds. II. A rapid method for the determination of fiber and lignin. JAOAC. 1963:(46):829-835.

2. Van Soest PJ. Development of a comprehensive system of feed analyses and its application to forages. J Anim Sci 1967;(26):119-128.

3. Tilley JMA, and Terry RA. A two stage technique for the in vitro digestion of forage of forage crops. J Br Grassland Soc 1963;(18):104-111.

4. Sniffen CJ, O'Connor JD, Van Soest PJ, Fox DG, Russell JB. A net carbohydrate and protein system for evaluating cattle diets: II. Carbohydrate and protein availability. J Anim Sci 1992;(70):3562-3577.

5. Fox DG, Tedeschi LO, Tylutki TP, Russell JB, Van Amburgh ME, Chase LE, Pell AN, Overton TR. The Cornell Net Carbohydrate and Protein System model for evaluating herd nutrition and nutrient excretion. Anim Feed Sci Technol 2004;(112)(1-4):29-78.

6. Lanzas C, Sniffen CJ, Seo S, Tedeschi LO, Fox DG. A revised CNCPS feed carbohydrate fractionation scheme for formulating rations for ruminants. Anim Feed Sci Technol 2007;(136):167-190. 
7. Van Amburgh ME, Collao-Saenz EA, Higgs RJ, Ross DA, Recktenwald EB, Raffrenato E, et al. The Cornell Net Carbohydrate and Protein System: Updates to the model and evaluation of version 6.5. J Dairy Sci 2015;(98):6361-6380.

8. Doane PH, Pell AN, Schofield P. Ensiling effects on the ethanol fractionation of forages using gas production. J Anim Sci 1998;76(3):888-895.

9. Molina DO. Prediction in intake of lactating cows in the tropics and of energy value of organic acids [doctoral thesis]. Ithaca, New York, USA: Cornell University; 2002.

10. Menke KHL, Raab A, Salewski H, Steingass D, Fritz Schneider W. The estimation of the digestibility and metabolizable energy content of ruminant feedingstuffs from the gas production when they are incubated with rumen liquor in vitro. J Agric Sci (Camb) 1979;(93):217-222.

11. Pell AN, Schofield P. Computerized monitoring of gas production to measure forage digestion in vitro. J Dairy Sci 1993;(76):1063-1073.

12. Schofield P, Pell AN. Measurement and kinetic analysis of the neutral detergent-soluble carbohydrate fraction of legumes and grasses. J Anim Sci 1995;(73):3455-3463.

13. Nutrient Requirements of Beef Cattle. 2016. National Academies of Sciences, Engineering, and Medicine. Eighth revised ed. Washington, DC: The National Academic Press.

14. Large Ruminant Nutrition System (LRNS) v1.033 http://nutritionmodels.com/lrns.html

15. Juarez-Lagunes FI, Fox DG, Blake RW, Pell AN. Evaluation of tropical grasses for milk production by dual-purpose cows in tropical Mexico. J Dairy Sci 1999;(82):2136-2145.

16. Ki KS, Su BP, Dong HL, Seongwon S. Evaluation of the nutritional value of locally produced forage in Korea using chemical analysis and in vitro ruminal fermentation. Asian-Australas J Anim Sci 2017;(30):(3):355-362.

17. Carvalho P, Da Silva CL, Nalcino FP, Scatolin OI, Dias LPR, Moreno FM. In vitro kinetic parameters of marandu palisadegrass associated with nonfiber carbohydrates. Semina: Ciências Agrárias, Londrina 2016;37(5):3253-3264.

18. Ribeiro RCO, Villela SDJ, Valadares Filho SC, Santos SA, Ribeiro KG, Detmann E, Zanetti D, Martins PGMA. Effects of roughage sources produced in a tropical environment on forage intake, and ruminal and microbial parameters. J Anim Sci 2015;(93):2363-2374. 
19. Tiwari UP, Turano B, Jha R. Nutritional characteristics and in vitro digestibility by nearinfrared spectroscopy of local and hybrid napiergrass varieties grown in rain-fed and irrigated conditions. Anim Prod Sci 2014;(54):1775-1778.

20. AOAC Official methods of analysis. 15th ed. Arlington, VA, USA: Association of Official Analytical Chemists. 1990.

21. Van Soest PJ, Robertson JB, Lewis BA. Methods for dietary fiber, neutral detergent fiber, and non-starch polysaccharides in relation to animal nutrition. J Dairy Sci 1991;(74):3583-3597.

22. Goering HK, Van Soest PJ. Forage fiber analysis (apparatus, reagents, procedures, and some applications). Washington, DC, USA: Agric. Handbook No. 379. ARS-USDA; 1970.

23. Hall MB, Lewis BA, Van Soest PJ, Chase LE. A simple method for estimation of neutraldetergent soluble fiber. J Sci Food Agric 1997;(74):441-449.

24. Schofield P, Pell AN. Validity of using accumulated gas pressure readings to measure forage digestion in vitro: a comparison involving three forages. J Dairy Sci 1995;(78):2230-2238.

25. Mertens DR, Loften JR. The effect of starch on forage fiber digestion kinetics in vitro. J Dairy Sci 1980;(63):1437-1446.

26. Stefanon B, Pell AN, Schofield P. Effect of maturity on digestion kinetics of watersoluble and water-insoluble fractions of alfalfa and brome hay. J Anim Sci 1996;(74):1104-1115.

27. Cone JW, Van Gelder AH, Visscher GJW, and Oudshoorn L. Influence of rumen fluid and substrate concentration on fermentation kinetics measured with a fully automated time related gas production apparatus. Anim Feed Sci Technol 1996;(61):113-128.

28. Minitab Inc. Minitab Reference Manual, Release 10, PC Version. Minitab Stat. Software. State College, Pensilvania, USA. 1994.

29. Arzate-Vázquez GL, Castrejón-Pineda FA, Rosiles-Martínez R, Carrillo-Pita S, ÁngelesCampos S, Vargas-Bello-Pérez E. Effect of genus and growth stage on the chemical and mineral composition of tropical grasses used to feed dairy cows. Cien Inv Agr 2016;43(3):476-485.

30. Lim F, Wong CC. Nutritive values and correlation equations on some improved tropical forages. MARDI Res J 1997;(202):173-180. 
31. Ramos-Santana R, McDowell LR. In vitro digestibility, crude protein content, and mineral concentrations of Cynodon, Brachiaria and Digitaria accessions in a humid tropical region of Puerto Rico. Commun Soil Sci Plant Annal 1996;(27):2687-2697.

32. Grant RJ, Perez CB Jr, Van Soest PJ, McDowell RE. Composition and in vitro true digestion of some Philippine feedstuffs. Philippine J Anim Sci 1973;(10):63-76.

33. Arroyo-Aguilú JA, Tessema S, McDowell RE, Van Soest PJ, Ramírez A, Randel PF. Chemical composition and in vitro digestibility of five heavily fertilized tropical grasses in Puerto Rico. J Agric Puerto Rico 1975;(59):186-198.

34. Poczynek M, Mikael N, Egon HH, Bruno JV, Danúbia NF, Milaine P, Galbeiro S. Mass and nutritional quality of upper and lower strata of tropical forages. Semina: Ciências Agrárias, Londrina 2016;37(4):Supl 1:2725-2736.

35. Espinoza-Guerra I, Pérez-Oñate C, Montenegro-Vivas L, Sánchez-Liaño A, GarcíaMartínez A, Martínez-Marín AL. Composition and in vitro rumen degradation kinetics of saboya grass (Megathyrsus maximus) silage with inclusion of passion fruit rind (Passiflora edulis Sims.). Rev Cient FCV-LUZ / 2016;(26):(6):402-407.

36. Lima RK, Carlos Augusto Brandão De CCA, Vidal AFH, Muninz MPA. Sward structure and nutritive value of Urochloa ruziziensis under nitrogen and potassium fertilization. Rev Caatinga Mossoró 2017;(30):(1):220-229.

37. Van Soest PJ. Nutritional ecology of the ruminant. Ithaca, New York, USA. Cornell University Press. 1994.

38. Weiss WP, Conrad HR, St. Pierre NR. A theoretically-based model for predicting total digestible nutrient values of forages and concentrates. Anim Feed Sci Technol 1992;(39):95-110.

39. Fukushima RS, Bacha CB, Fuzeto AP, Port ACR, Herling VR, Velasquez AV. Utilization of equations to predict carbohydrate fractions in some tropical grasses. Anim Feed Sci Technol 2015;(208):12-22.

40. Bezabih M, Pellikaan WF, Tolera A, Khan NA, Hendriks WH. Chemical composition and in vitro total gas and methane production of forage species from the Mid Rift Valley grasslands of Ethiopia. Grass Forage Sci 2013;(69):4.

41. Ellis RP. Tannin-like substances in grass leaves. Mem Bot Survey S Africa 1990;(59):378.

42. Oliveira EM, Oliveira FJ, Oliveira RA, Oliveira RM, Cecon RP. Determination of Xaraés grass quality submitted to irrigation water levels and nitrogen and potassium doses. J Brazilian Assoc Agr Engineering 2017;(37):(1):64-74. 
43. Campos FP, Nicacio DRO, Sarmento P, Cruz MCP, Santos TM, Faria AFG, Ferreira ME, Conceicao MRG, Lima CG. Chemical composition and in vitro ruminal digestibility of hand-plucked samples of Xaraes Palisade grass fertilized with incremental levels of nitrogen. Anim Feed Sci Technol 2016;(215):1-12.

44. Campos FP, Sarmento P, Nussio LG, Lugão SMB, Lima CG. Fiber monosaccharides and digestibility of Milenio grass under $\mathrm{N}$ fertilization. Anim Feed Sci Technol 2013;(183):17-21.

45. Mertens DR. Application of theoretical mathematical models to cell wall digestion and forage intake in ruminants [doctoral thesis]. Ithaca, New York, USA: Cornell University; 1973.

46. Raffrenato E, Erasmus LJ. Variability of indigestible NDF in C3 and C4 forages and implications on the resulting feed energy values and potential microbial protein synthesis in dairy cattle. South African J Anim Sci 2013;43(5):(Suppl 1).

47. Huhtanen P, Seppala A, Ots M, Ahvenjarvi S, Rinne M. In vitro gas production profiles to estimate extent and effective first-order rate of neutral detergent fiber digestion in the rumen. J Anim Sci 2008;(86):651-659.

48. Detmann E, Coelho da Silva JF, Maldonado VH, Lara TH, Ramalho HI. Kinetic parameters of carbohydrates ruminal degradation of four tropical grasses in different cutting ages and nitrogen fertilizer levels. R Bras Zootec 2009;38(1):149-158.

49. Wilson JR. Cell wall characteristics in relation to forage digestion by ruminants. J Agric Sci (Camb) 1994;(122):173-182. 